\title{
中耳真珠腫再発に関する前鼓室開放術の有用性
}

一耳管機能からみた評価一

$$
\begin{aligned}
& \text { 松本 毅・楠見 妙子・吳 孟達 } \\
& \text { 中山 明峰・稲福 繁・石神 寛通 }
\end{aligned}
$$

\section{Retorospective Evaluation of the Role of Anterior Tympanotomy in Reccurent Middle Ear Cholesteatoma Cases Based upon Eustachian Tube Function}

\author{
Tsuyoshi Matsumoto, Taeko Kusumi, Men-dar Wu, \\ Meiho Nakayama, Shigeru Inafuku and Hiromichi Ishigami \\ (Aichi Medical University)
}

It is well known that dysfunction of the eustachian tube can cause retraction of the ear drum, and resultant cholesteatoma. In this study, we investigated retrospectively the relationship between reccurence of middle ear cholesteatoma and eustachian tube function.

From 1993 to 1996, 81 cholesteotoma patients (83 ears) received intact canal wall tympanoplasty in the Department of Otolaryngology at Aichi Medical University. Before surgery, we evaluated their eustachian tube function by sonotubometry and tubotympano aerodynamic graphy (TTAG).

They were divided into four groups based upon the presence of a normal or dysfunctional eustachian tube and whether or not they received anterior tympanotomy. The rate of recurrence was lowest in the group who had normal function of the eustachian tube and previous anterior tympanotomy. In contrast, recurrence was most in the group who had a dysfunctional eustachian tube and did not receive anterior tympanotomy.

These results indicate that aeration of the middle ear is a significant factor in preventing recurrence of cholesteatoma.

Key words : eustachian tube, cholesteatoma, sonotubometry, TTAG, anterior tympanotomy

はじめに

中耳真珠腫の成因または病態に関する諸説の中，中耳 腔の換気能障害が真珠腫の発症に最も密接な関係を持つ ことは古くから認識されているが，詳細に至る部分はま だ議論のあるところである。また耳管機能の障害が術後 経過にどのように影響しているか未だ見解が一致してい ないのが現状である.

一方, 森満1) は再発性再発真珠腫の発病機序は初発真 珠腫発症の機序と同じものであると述べ，真珠腫再発因
子の検証は真珠腫の病態解明に重要な意義が持たれるこ とが考觉られる.

本報告では，耳管音響法拉よび耳管鼓室気流動態法 (以下 TTAG) の結果ならび前鼓室開放術の併用の有無 をパラメータとして, 真珠腫術後再発を回顧的に検討し た.

\section{方法, 調查対象}

対象は1992年から1996年までの過去 5 年間当科にて外 
耳道保存鼓室形成術を施行した中耳真珠腫症例のらち, 術前耳管機能検査法にて患耳の耳管機能の評価ができた 81例，83耳の症例である. 術後の観察期間としては術後 最低 2 年間が経過した症例で，その期間中に局所所見で 明らかな debris の貯留を伴ら鼓膜の陷凹，もしくは癒 着がみられたものを真珠腫の再発性再発とした.ただし， 遺残が確認されたものは今回の検討対象外とした．年齢 分布は最少齢が 9 歳, 最高齢が65歳であり，40歳代が最 も多く, 次いで50歳代，30歳代の順であった，そのらち 男性44例46耳，女性37例37耳であった（図 1 )。 また，同 一症例の上述の期間内に打ける段階手術は 1 症例のみで あった。

経耳管的換気，圧調節機構を評価するパラメーターに は受動的開大能と能動的開大能がある. 受動的開大能は カテーテル通気やValsalva 法などの外圧による耳管の 開さ易さを示すのに対し，能動的開大能は嚥下による耳 管の開き易さを示す. 受動的開大能検査として，TTAG と鼓膜穿孔耳に用いられる逆通気圧テストがあり, 能動 的開大能検査として耳管音響法と加圧・減圧テストがあ る.

これらの耳管機能検査法のらち, 一般的にはスクリー ニング検査法として自然な生理状態下の能動的耳管開大 能を測定する耳管音響法が最も頻用されているが，実際 の耳管換気能はほとんど反映されていない。それに対し て，Valsalva 法によるTTAG は手技上の問題によって 症例の適応が制限されるが，基本的には耳管の受動的開
大能以外に耳管換気能も観察可能となる.よって，今回 耳管機能の評価にはこの二つの検査法を用いた，検査装 置およびそれぞれの判定基準は次の通りである.

使用器械としてはリオン社製耳管機能検査装置 JK-04 を用いた、耳管音響法の検査成績の判定については外耳 道内音圧が $10 \mathrm{~dB}$ 以上, かつ耳管開放時間が $100 \mathrm{msec}$ 以上のものを耳管開大能良好例とし，それ以外のものは 耳管開大能不良例とした。一方，TTAG の場合はValsalva 法によって少なくとも外耳道内圧が $20 \mathrm{~mm}$ 水柱 以上の上昇が検出され，乙か子数回の燕下にてその外耳 道内残圧 (residual pressure；RP) が常圧にまで解除さ れるものを耳管換気能良好例とし，それ以外のものは耳 管換気能不良例とした（表 1)。ただし，すべてのValsalva 法不適例は検討対象から除外した2).

\section{結果}

耳管音響法を施行し評価可能であった症例が83耳であ り，このらち TTAG も併せて施行できたものが83耳中 61耳あった。

1 ) 真珠腫の病型と耳管機能検査成績の関係(表 $2 \sim$ 4)

耳管音響法による耳管開大能の良否でみてみると，開 大能良好 83 耳中 24 耳 $(29 \%)$, 開大能不良 83 耳中 59 耳 $(71$ \%)であった。またTTAG では耳管換気能良好例は61 耳中25耳 $(41 \%)$ ，耳管換気能不良例は36耳(59\%)であっ

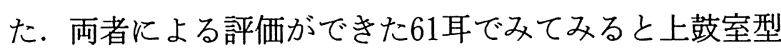

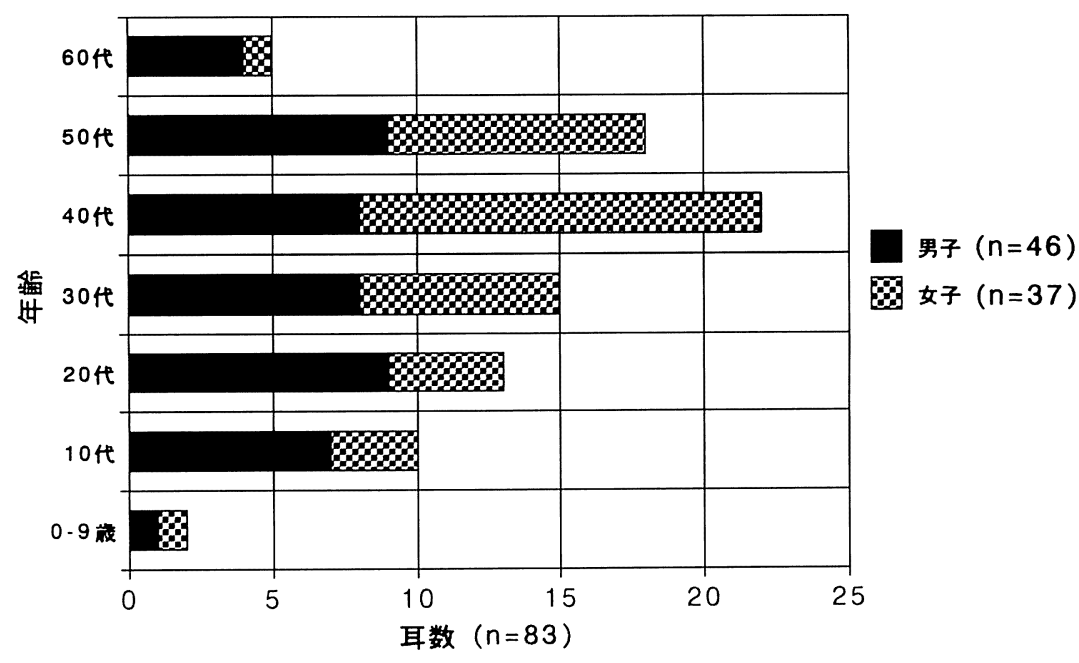

図 1 年齢階層別执よび性別分布 
表 1 能動的耳管開大能と能動的耳管換気能の評価法

\section{音響耳管法による能動的耳管開大能の評価 \\ 計測機械 : RION JK-04 耳管機能検査装置 \\ 鼻咽腔に負荷音 $(7000 \mathrm{~Hz}$ バンドノイズ)を与え，䲆下に \\ よる耳管の開閉に伴ら外耳道負荷音をマイクロホンに \\ て検出 \\ * 以下の条件を満たしたものを耳管開大能良好例とす る \\ 外耳道内音圧 (external auditory S. P. ) $\geqq 10 \mathrm{~dB}$ かつ \\ 耳管開放時間 (duration) $\geqq 100 \mathrm{mec}$}

TTAG 法による能動的耳管換気能の評価 計測機械 : RION JK-04 耳管機能検査装置

Valsalva 法耳管通気による中耳腔内圧の変化を鼓膜を 介した外耳道圧の変化として，圧トランスデューサに接 続した外耳道プローブにて検出

* 以下の条件を満たしたものを耳管換気能良好例とす る

外耳道内圧 $\geqq 20 \mathrm{~mm}$ 水柱の上昇

数回の燕下にて外耳道内残圧 (residual pressure:

RP) が平衡化される

*Valsalva 法不適例は検討対象外

では45耳中 11 耳 $(24 \%)$ は開大能，換気能ともに良好であ り，逆にともに不良であった例は 21 耳 $(47 \%)$ を占めた。 同様に後上象限癒着穿孔型では, 両検査共良好は 13 耳中 2 耳 $(15 \%)$ ，両検查共不良は 8 耳 $(62 \%)$ を占めた。全体 では，61耳中 14 耳 $(23 \%) ， 61$ 耳中 31 耳 $(51 \%)$ であり，開 大能，換気能ともに不良な例が半数を占めた.

2 ）前鼓室開放術の併用と耳管開大能からみた術後成 績(表 5 )

前豉室開放術 ${ }^{11}$ は前鼓室，上鼓室の換気改善をはかる ことで再発を防止する目的に施行される術式である. 次 に術前耳管機能検查結果と前鼓室開放術との相関を検討 した．実際の開放術施行の適応条件については各術者の
表 2 真珠腫の病型および耳管音響法 (耳管開大能)の関係

\begin{tabular}{c|c|c|c}
\hline \hline & $\begin{array}{c}\text { 耳管開大能 } \\
\text { 良 }\end{array}$ & $\begin{array}{c}\text { 耳管開大能 } \\
\text { 不良 }\end{array}$ & 計 \\
\hline 上鼓室型 & 17 & 44 & 61 \\
\hline 後上象限瘉着穿孔型 & 6 & 13 & 19 \\
\hline 緊張部穿孔型 & 1 & 2 & 3 \\
\hline 計 & $\begin{array}{c}24 \\
(29 \%)\end{array}$ & $\begin{array}{c}59 \\
(71 \%)\end{array}$ & 83
\end{tabular}

表 3 真珠腫の病型および TTAG (耳管換気能)の関俰

\begin{tabular}{c|c|c|c}
\hline \hline & $\begin{array}{c}\text { 耳管換気能 } \\
\text { 良 }\end{array}$ & $\begin{array}{c}\text { 耳管換気能 } \\
\text { 不良 }\end{array}$ & 計 \\
\hline 上鼓室型 & 21 & 24 & 45 \\
\hline 後上象限癒着穿孔型 & 3 & 10 & 13 \\
\hline 緊張部穿孔型 & 1 & 2 & 3 \\
\hline 計 & $\begin{array}{c}25 \\
(41 \%)\end{array}$ & $\begin{array}{c}36 \\
(59 \%)\end{array}$ & 61
\end{tabular}

術中所見に基づいた判断に委ねられている.

まず耳管開大能良否に着目して再発率をみてみると， 前鼓室開放術施行にかかわらず術前耳管機能検査で開大 能良好耳24耳すべてに再発は認められなかった。逆に， 開大能不良耳では59耳中17耳 $(29 \%)$ に再発がみられ，前 鼓室開放術を施行した場合 24 耳中 5 耳 $(21 \%)$ に，そして 前鼓室開放術未施行群では 35 耳中 12 耳 $(35 \%)$ に再発が認 められた。

3 ）前鼓室開放術の併用と耳管換気能からみた術後成 績(表 6 )

次に耳管換気能の良否で再発率をみてみると，前豉室 開放術を施行した 26 耳中 4 耳 $(15 \%)$ に，また，未施行例 に怙いては 35 耳中 10 耳 $(29 \%)$ に再発が認められた．換気 能良好で開放術を施行した場合の再発は10耳中 1 耳 $(10$ \%)で，未施行の場合15耳中 2 耳(13\%)であった．換気

表 4 真珠腫の病型および耳管音響法・TTAG の関係

\begin{tabular}{|c|c|c|c|c|c|}
\hline & $\begin{array}{ll}\text { 耳管開大能 } & \text { 良 } \\
\text { 耳管換気能 } & \text { 良 }\end{array}$ & $\begin{array}{l}\text { 耳管開大能 良 } \\
\text { 耳管換気能 } \quad \text { 不良 }\end{array}$ & $\begin{array}{lr}\text { 耳管開大能 } & \text { 不良 } \\
\text { 耳管換気能 } & \text { 良 }\end{array}$ & $\begin{array}{l}\text { 耳管開大能 不良 } \\
\text { 耳管換気能 不良 }\end{array}$ & 計 \\
\hline 上鼓室型 & 11 & 3 & 10 & 21 & 45 \\
\hline 後上象限癒着穿孔型 & 2 & 2 & 1 & 8 & 13 \\
\hline 緊張部穿孔型 & 1 & 0 & 0 & 2 & 3 \\
\hline 計 & 14 & 5 & 11 & 31 & 61 \\
\hline
\end{tabular}


表 5 前豉室開放術の併用と耳管開大能からみた術後成績

\begin{tabular}{c|c|c|c}
\hline \hline & $\begin{array}{c}\text { 耳管開大能 } \\
\text { 良 }\end{array}$ & $\begin{array}{c}\text { 耳管開大能 } \\
\text { 不良 }\end{array}$ & 計 \\
\hline $\begin{array}{c}\text { 前鼓室開放術 } \\
\text { 施行 }\end{array}$ & $0 / 10$ & $\begin{array}{c}5 / 24 \\
(21 \%)\end{array}$ & $\begin{array}{c}5 / 34 \\
(15 \%)\end{array}$ \\
\hline $\begin{array}{c}\text { 前鼓室開放術 } \\
\text { 未施行 }\end{array}$ & $0 / 14$ & $\begin{array}{c}12 / 35 \\
(35 \%)\end{array}$ & $\begin{array}{c}12 / 49 \\
(24 \%)\end{array}$ \\
\hline 計 & $0 / 24$ & $\begin{array}{c}17 / 59 \\
(29 \%)\end{array}$ & $\begin{array}{c}17 / 83 \\
(20 \%)\end{array}$
\end{tabular}

上段 : 再発耳数/症例耳数

下段 : 再発率

表 6 前鼓室開放術の併用と耳管換気能からみた術後成績

\begin{tabular}{c|c|c|c}
\hline \hline & $\begin{array}{c}\text { 耳管換気能 } \\
\text { 良 }\end{array}$ & $\begin{array}{c}\text { 耳管換気能 } \\
\text { 不良 }\end{array}$ & 計 \\
\hline $\begin{array}{c}\text { 前鼓室開放術 } \\
\text { 施行 }\end{array}$ & $\begin{array}{c}1 / 10 \\
(10 \%)\end{array}$ & $\begin{array}{c}3 / 16 \\
(19 \%)\end{array}$ & $\begin{array}{c}4 / 26 \\
(15 \%)\end{array}$ \\
\hline $\begin{array}{c}\text { 前臌室開放術 } \\
\text { 未施行 }\end{array}$ & $\begin{array}{c}2 / 15 \\
(13 \%)\end{array}$ & $\begin{array}{c}8 / 20 \\
(40 \%)\end{array}$ & $\begin{array}{c}10 / 35 \\
(29 \%)\end{array}$ \\
\hline 計 & $\begin{array}{c}3 / 25 \\
(12 \%)\end{array}$ & $\begin{array}{c}11 / 36 \\
(31 \%)\end{array}$ & $\begin{array}{c}14 / 61 \\
(23 \%)\end{array}$
\end{tabular}

上段 : 再発耳数/症例耳数

下段 : 再発率

能不良では施行例が16耳中 3 耳 $(19 \%)$ ，未施行例が 20 耳 中 8 耳 $(40 \%)$, 全体では 36 耳中 11 耳 $(31 \%)$ の再発が認め られた。

4 ）前鼓室開放術の併用と耳管開大能・換気能からみ た術後成績 (表 7 )

開大能, 換気能の両者を併せてみてみると, 開大能が 良好であれば換気能の良否, 前鼓室開放術の併用の有無 にかかわらず再発は認められなかった。開大能が不良か つ換気能が良好群では, 前鼓室開放術を施行しても 4 耳
中 1 耳に再発をきたし，また未施行例では 7 耳中 2 耳に 再発が欢ら大差はなかった。中でも特に注目すべきは 両検査結果が不良で, かつ前鼓室開放術未施行群であり 16 耳中 8 耳 $(50 \%)$ に再発が認められたことである.

結果的には開放術の施行が最も術後の再発成績に影響 を及ぼすのは耳管機能不良群であった。

中耳真珠腫に扣いて術前の耳管機能検査結果は術後の 鼓膜変化，再発に相関する可能性が示唆された.

\section{考察}

術前の耳管機能が術後経過や予後にどのような影響を 及洔すかいまだ見解が一致しない，さらにこれまで精度 の高い耳管機能検査装置がなかったことや，耳管機能の 評価法が確立していなかったこともこの問題が未解決で ある一因とされる．最近まで，あるいは現在でも耳管力 テーテルによる通気法の通気音のみが臨床上でのよりど ころである. しかし通気音聴取に基づく耳管機能の判定 はあくまでも主観的なものであり，耳鼻咽喉科医の熟練 度にゆだねられている部分が多い。近年, 総合的耳管機 能検查装置が開発され ${ }^{3)}$, 受動的開大能p能動的開大能 が容易に測定でき，かつ多施設での客観的比較検討が可 能になった。

現在臨床に応用されている耳管機能評価法としてまず 第一に耳管音響法があり，この原理は1869年 Politzer4) が鼻孔近くに置いた音叉の音が耳管を通って中耳に伝わ ることを報告したのが最初である。その後, Perlman ${ }^{5)}$ を初めとして欧米扣よび本邦で音響を利用した耳管機能 検査法が発表されたが，なかなか一般化されなかった。 現在わが国で臨床に用いられている検査機器は, 大久保 ら年が考案した装置が基となっている. 次に TTAGは1 974年に Kumazawa ら ${ }^{7)}$ にって報告されたものであり，

表 7 前鼓室開放術の併用と耳管開大能・換気能からみた術後成績

\begin{tabular}{|c|c|c|c|c|c|}
\hline & $\begin{array}{cc}\text { 耳管開大能 } & \text { 良 } \\
\text { 耳管換気能 } & \text { 良 }\end{array}$ & $\begin{array}{lr}\text { 耳管開大能 } & \text { 良 } \\
\text { 耳管換気能 } & \text { 不良 }\end{array}$ & $\begin{array}{lr}\text { 耳管開大能 } & \text { 不良 } \\
\text { 耳管換気能 } & \text { 良 }\end{array}$ & $\begin{array}{l}\text { 耳管開大能 不良 } \\
\text { 耳管換気能 不良 }\end{array}$ & 計 \\
\hline 前鼓室開放術施行 & $0 / 6$ & $0 / 1$ & $\begin{array}{c}1 / 4 \\
(25 \%)\end{array}$ & $\begin{array}{r}3 / 15 \\
(20 \%)\end{array}$ & $4 / 26$ \\
\hline 前鼓室開放術未施行 & $0 / 8$ & $0 / 4$ & $\begin{array}{c}2 / 7 \\
(29 \%)\end{array}$ & $\begin{array}{r}8 / 16 \\
(50 \%)\end{array}$ & $10 / 35$ \\
\hline 計 & $0 / 14$ & $0 / 5$ & $3 / 11$ & $11 / 31$ & $14 / 61$ \\
\hline
\end{tabular}


原理はValsalva 法耳管通気が基本となっている。その 他，加圧 ·減圧耳管機能検査は Flisberg $5^{8)}$ によって 圧平衡法として用いられ, Silverstein ら9)により出性 中耳炎などの検査に利用された。 その後 Bluestone ら 10$)$ によって受動的圧測定法が加わり現在の加圧・減圧法と して確立された。

これらが基となりこれまで様々な報告がなされてきた。 Holmquist $^{11)}$, MacKinnon ${ }^{12)}$, Cohn $5^{13)}$, Sato $5^{14)}$, 島田 ${ }^{15)}$, 岩野ら ${ }^{16)}$, 二宮 ${ }^{17)}$, 藤田 ${ }^{18)}$, 石川 ${ }^{19)}$ は術前耳管 検査結果と術後経過との間に相関性があると論じている のに対し, Andreasson $5^{20)}$, Bluestone $5^{21)}$, Ekvall22) は加圧・減圧法による耳管機能検査で両者の相関性を否 定している.

Palva $5^{23)}$ は受動的開大能を検討し術前耳管機能検査 結果と手術成績との間に相関性を認め, Virtanen ら 24$)$ も耳管音響法と加圧・減圧法を術前に施行し, 耳管音響 法の結果が術後成績とよく相関すると結論している.

このように，耳管機能と鼓室形成術に関する報告は数 多くみられ，耳管機能の良い症例に括いて鼓室形成術の 術後経過は良好であったといら報告がある一方でその関 係に否定的な報告もあり，耳管機能と耳手術との関係に 統一した結果はみられない。

しかしながら今回われわれの行った中耳真珠腫の術前 耳管機能検査結果と術後の鼓膜変化さらには再発との検 討では，かなりの相関性が認められた。術前耳管機能検 査に拈いて耳管開大能が良好であれば，前鼓室開放術の 併用の有無にかかわらず経過は良好であったのに対し， 能動的開大能, 受動的開大能, および換気能ともに障害 されている症例では高率に術後, 鼓膜の内陥, 癒着, コ ルメラ突出などが生じて括り, 術中に前鼓室開放術を加 えることで術後の再発率を低下させることが可能である という結果に至った. このことは術前耳管機能検查の結 果が手術術式の選択に有用であることを示唆している. また，TTAGに比べ耳管音響法の結果がより術後経過 を反映し相関しているといらことが明らかとなった。

今回，われわれの検討では耳管機能障害例に対する前 鼓室開放術の併用は再発防止に有効である.これは森 満1) の前鼓室開放術は術後の鼓膜内陥を予防するといら 報告に一致する.よって積極的な前鼓室開放術の施行が 真珠腫の治癒成績に大きく寄与するといら結論に至った. 今後, 真珠腫の成立機転の解明や術後経過に対する耳 管機能障害の関与が, 総合的耳管機能検査装置の普及に
伴いさらに明らかになっていくものと考えられる。

$$
\text { まとめ }
$$

中耳真珠腫の術後成績を耳管機能検査の評価，また前 鼓室開放術併用の有無により検討した．今回の検討で示 唆されたように中耳真珠腫では術前の耳管機能検査が必 要である.耳管機能不良例，特に耳管開大能・換気能共 に不良，かつ前鼓室開放術未施行例では高率に再発がみ られた。 しかし前鼓室開放術施行により再発率を低下さ せることが可能であり，このことから中耳換気能改善を 目的とした前鼓室開放術の併用は有用であるといら結論 に至った.よって耳管機能検査の結果をらまえた上で手 術術式の決定がなされるべきである.

本論文の内容は第91回日本耳鼻咽喉科学会東海地方部会連合 講演会に揖いて報告した。

\section{参考文献}

1) 森満 保：中耳真珠腫の発症 一特に前鼓室の意義一.耳 鼻 $37: 392 \sim 393,1991$.

2 ) 郡山智也, 白木直也, 稲福 繁, 他 : 耳管機能検査. 現代 医学 $44: 421 \sim 431,1997$.

3 ) 山下敏夫, 岩野 正, 熊沢忠躬, 他 : 耳管機能検查の臨床 応用とその問題点. 耳展 $34: 113 \sim 132,1991$.

4) Politzer A, 1869 cited by Politzer A, 1908 : Lehrbuch der Ohrenheilkunde. 5th ed, Vol 1. Stuttgart : F Enke, 1908

5 ) Perlman HB : The eustachian tube; abnormal patency and normal physiologic state. Arch Otolaryngol $30: 212$ 〜238, 1939.

6 ）大久保仁, 石川紀彦, 大柿 徹, 他 : 音響耳管機能検査法 一(続) WIO-01 型試作機の使用経験一. 耳鼻臨床 77 : 1747 1754, 1984.

7 ) Kumazawa T, Honjo I and Honda K : Aerodynamic evaluation of eustachian tube function. Arch Otolaryngol $208: 147 \sim 156,1974$.

8 ) Flisberg $\mathrm{K}$, Ingelstedt $\mathrm{S}$, Ortegren $\mathrm{U}$, et al : On middle ear pressure. Acta Otolaryngol (Stockh) Suppl $182: 43 \sim 56$, 1963.

9 ) Silverstein H, Miller GF and Lindeman RC : Eustachian tube dysfunction as a cause for secretory otitis in children. Laryngoscope $76: 259 \sim 273,1966$.

10) Bluestone CD, Paradise JL and Beery QC : Symposium on prophalaxis and treatment of middle ear effusion. $\mathrm{N}$ Physiology of the eystachian tube in the pathgenesis and management of middle ear effusion. Laryngoscope 82 : 
$1654,1972$.

11) Holmquist $J$ : The role of the eustachian tube in myringoplasty. Acta Otolaryngol (Stockh) $66: 289 \sim 295,1968$.

12) MacKinnon DM : Relationship of pre-operative eustachian tube function to myringoplasty. Acta Otolaryngol (Stockh) $69: 100 \sim 106,1970$.

13) Cohn AM, Schwaber MK, Anthony LS, et al : Eustachian tube function and tympanoplasty. Ann Otol Rhinol Laryngol $88:$ 339 347, 1979.

14) Sato H, Nakamura $H$, Honjo I, et al : Eustachian tube function in tympanoplasty. Acta Otolaryngol (Stockh) Suppl $471: 9 \sim 12,1990$.

15）島田士郎：耳管換気能と乳突蜂巣の関係扣よび耳管換気能 と鼓室形成術の術後経過に関する研究. 耳展 34 補 $6: 503$ 〜 518, 1991.

16）岩野 正, 熊沢忠躬, 山下敏夫 : 中耳手術と耳管機能. 耳 展 $37: 141 \sim 151,1994$.

17）二宮靖子，柊山幹子，東野哲也，他：鼓室形成術術前検査 としての耳管機能検査装置の有用性の検討.耳鼻 $42: 814$ $\sim 819,1996$.

18）藤田昭彦, 倉田響介, 高北晋一, 他 : 鼓室形成術後の鼓室 の含気化と耳管換気能 一CT による評価一. 耳鼻臨床 87 : 1509 1513, 1994.
19）石川紀彦：音響耳管機能検査法．耳喉頭頸 $66: 527 \sim 532$, 1994.

20) Andreasson $L$ and Harris $S$ : Middle ear mechanics and eustachian tube function in tympanoplasty. Acta Otolaryngol (Stockh) Suppl $360: 141 \sim 147,1979$.

21) Bluestone CD, Cantekin EI and Douglas GS : Eustachian tube function related to the results of tympanoplasty in children. Laryngoscope $89: 450 \sim 458,1979$.

22) Ekvall L : Eustachian tube function in tympanoplasty. Acta Otolaryngol (Stockh) Suppl $263:$ 33 42, 1970.

23) Palva A and Karja J : Eustatian tube patency in chronic ear, pre-operative evaluation correlated to postoperative results. Acta Otolaryngol (Stockh) Suppl $263: 25 \sim 28$, 1970.

24) Virtanen $H$, Palva $T$ and Jauhiainen $T$ : The prognostic value of eustachian tube function measurements in tympanoplastic surgery. Acta Otolaryngol (Stockh) $90: 317$ $\sim 323,1980$.

$\left(\begin{array}{l}\text { 別刷請求先 : 松本 毅 } \\ \text { †480-1195 愛知県愛知郡長久手町岩作字雁又 } 21 \\ \text { 愛知医科大学耳鼻咽喉科学教室 }\end{array}\right)$

